\title{
The Average Values and Phenotypical Correlations of the Qualitative Milk Parameters in Carpathian Goat Breed, Estimated Function of Genotypes from the $\alpha_{\mathrm{s} 1}$ - casein Locus
}

\author{
Bogdan VLAIC, Valentin A. BĂLTEANU, Viorica COŞIER, Augustin VLAIC* \\ Faculty of Animal Science and Biotechnology, University of Agricultural Science and Veterinary \\ Medicine Cluj-Napoca, Romania \\ *Corresponding author, email: avlaic@usamvcluj.rob
}

Bulletin UASVM Animal Science and Biotechnologies 71(2) / 2014,

Print ISSN 1843-5262; Electronic ISSN 1843-536X

DOI:10.15835/buasvmcn-asb:10765

\begin{abstract}
The content of $\alpha_{\mathrm{s} 1}$-casein in goat milk varies in wide limits from an individual to another (0-7.2 g/L) due to the complex genetic polymorphism of this protein. Between the 18 genetic variants (alleles) there are big differences concerning the expression level of this protein in milk (Grosclaude et al., 1987; Mahe et al., 1994; Caroli et al., 2006). The aim of this paper was to report the average values and phenotypical correlations of the qualitative parameters of goat milk (the content of fat, protein, casein, lactose, unfatty dry matter) function of genotypes identified at $\alpha_{\mathrm{s} 1}$ - casein locus by the isoelectric focusing technique (IEF). The average values of the analyzed parameters are different function of genotype, the biggest values being recorded in homozygous AA genotype, and the smallest in the homozygous FF genotype. The most numerous positive correlations, intense and significant between the qualitative milk parameters are recorded in homozygous AA genotype. In conclusion, allele A from the CSN1S1 locus, which codifies $\alpha_{\mathrm{S} 1}$-casein in goat has advantages in genetic markers assisted selection (MAS).
\end{abstract}

Keywords: $\alpha_{s 1}$-casein, Carpathian, correlations, genotypes, goats

\section{INTRODUCTION}

The CSN1S1 gene, which codifies $\alpha_{\mathrm{S} 1}$-casein has a total length of $16,785 \mathrm{bp}$ that include 19 exonic regions and 18 intronic regions. The mature protein of $\alpha_{\mathrm{s} 1}$-casein is formed of 199 amino acids (Ramuno et al., 2004 cited by Pop, 2012).

The content of $\alpha_{\mathrm{s} 1}$ - casein in goat milk varies in wide limits from an individual to another (0-7.2 $\mathrm{g} / \mathrm{L}$ ) due to the complex genetic polymorphism of this protein. The studies concerning the polymorphisms of gene, performed at protein level, and then at DNA level emphasized that between the 18 genetic variants (alleles) there are big differences concerning the expression level of this protein in milk, with implication on milk quality, processing properties and cheese obtaining yield (Grosclaude et al., 1987; Mahe et al., 1994; Caroli et al., 2006).
Function of the contribution they have on the protein content from milk, these alleles may be grouped in four categories:

1) alleles with strong expression of $3.6 \mathrm{~g} \alpha_{\mathrm{S} 1}-\mathrm{CN} /$ allele/L (A, B, C, H, L, M);

2) alleles with aveage expression 1.1g $\alpha_{\mathrm{s} 1}-\mathrm{CN} /$ allele /L (E, I);

3) alleles with weak expression $0.45 \mathrm{~g} \alpha_{\mathrm{S} 1}-\mathrm{CN} /$ allele /L (D, F, G);

4) nulls alleles, characterized by absence of this protein in milk of the homozygous individuals $\left(\mathrm{O}_{1}, \mathrm{O}_{2}, \mathrm{~N}\right)$.

In Carpathian goat population, the alleles with strong expression $(A, B, C)$ have a frequency equal to 0.583 , those with average and weak expression (E, F) equal to 0.390 and no expression (0) with 0.027 (Pop, 2012). 
The aim of the research was to estimate the average values and differences between them function of genotypes identified at CSN1S1 locus, which codifies $\alpha_{\mathrm{s} 1}$-casein, and to estimate within each genotype the phenotypical correlations of qualitative parameters of goat milk in Carpathian goat breed.

\section{MATERIALS AND METHODS}

The genotypes at CSN1S1 locus, which codify $\alpha_{\mathrm{s} 1}$-casein (AA, EE, FF, and heterozygous), were established by the isoelectric focusing technique (IEF) direct from milk samples. The qualitative parameters of the goat milk (the contents of: fat, protein, casein, lactose, unfatty dry matter-UDM and $\mathrm{pH}$ ) were quantified within the laboratory of the Foundation for the Milk Quality Control from Floreşti-Cluj using accredited and well-established methods. The average values and correlation between the milk qualitative parameters were calculated using STATISTICA V 7.0. programme.

The qualitative parameters of milk were determined based on the average between two individual controls performed during lactation (June-July) function of the genotype category (AA, $\mathrm{EE}, \mathrm{FF}$, and heterozygote), summing a total number of 105 analyzed milk samples.

\section{RESULTS AND DISCUSSION}

In Table 1 are presented the average values of the qualitative parameters (physico-chemical) of goat milk, estimated function of genotypes of the $\alpha_{\mathrm{s} 1}$-casein.

The average values of the analyzed parameters are different function of genotype, the biggest values being recorded in homozygous AA (except the lactose content and $\mathrm{pH}$ ), and the smallest in homozygous FF genotype. Except $\mathrm{pH}$, the average values of the homozygous genotype $\mathrm{EE}$ are between values of the AA and FF homozygous. The heterozygous genotypes ( $\mathrm{AE}, \mathrm{AF}$ and $\mathrm{EF}$ ) record the lowest average values for fat content, UDM and $\mathrm{pH}$.

In Table 2 are presented the differences between the average values of the genotypes from the locus of the $\alpha_{\mathrm{s} 1}$-casein concerning the qualitative parameters of the goat milk.

The differences between the average values of the AA homozygous genotype and other genotypes (EE, FF and heterozygous), are statistically assured at different thresholds of significance in advantage of the AA genotype for the content of total protein, casein content and UDM content, and for the rest of parameters the differences are not significant.

The differences distinctly significant $(p \leq 0.01)$ in advantage of the homozygous EE genotype

Tab. 1. The average values of qualitative parameters of goat milk estimated function of the genotypes of the $\alpha_{\mathrm{s} 1}$-casein

\begin{tabular}{|c|c|c|c|c|c|c|c|c|}
\hline \multirow{3}{*}{$\begin{array}{l}\text { Analyzed } \\
\text { parameters }\end{array}$} & \multicolumn{3}{|c|}{$\mathrm{AA}$} & \multirow[t]{2}{*}{$\mathrm{EE}$} & \multicolumn{3}{|c|}{$\mathrm{FF}$} & \multirow{3}{*}{$\begin{array}{l}\text { Heterozygous } \\
\qquad \bar{X} \pm s_{\bar{X}}\end{array}$} \\
\hline & $\mathrm{n}$ & & $\mathrm{n}$ & & $\mathrm{n}$ & & $\mathrm{n}$ & \\
\hline & & $\bar{X} \pm s_{\bar{X}}$ & & $\bar{X} \pm s_{\bar{X}}$ & & $\bar{X} \pm s_{\bar{X}}$ & & \\
\hline $\begin{array}{l}\text { Fatness } \\
(\mathrm{g} / 100 \mathrm{~g})\end{array}$ & 49 & $3.67 \pm 0.13$ & 11 & $3.64 \pm 0.13$ & 26 & $3.57 \pm 0.10$ & 19 & $3.14 \pm 0.09$ \\
\hline $\begin{array}{l}\text { Protein } \\
(\mathrm{g} / 100 \mathrm{~g})\end{array}$ & 49 & $3.57 \pm 0.12$ & 11 & $3.15 \pm 0.22$ & 26 & $3.06 \pm 0.05$ & 19 & $3.14 \pm 0.05$ \\
\hline $\begin{array}{l}\text { Casein } \\
(\mathrm{g} / 100 \mathrm{~g})\end{array}$ & 49 & $2.64 \pm 0.09$ & 11 & $2.32 \pm 0.10$ & 26 & $2.27 \pm 0.03$ & 19 & $2.33 \pm 0.04$ \\
\hline $\begin{array}{l}\text { Lactose } \\
(\mathrm{g} / 100 \mathrm{~g})\end{array}$ & 49 & $4.26 \pm 0.05$ & 11 & $4.31 \pm 0.08$ & 26 & $4.41 \pm 0.03$ & 19 & $4.18 \pm 0.02$ \\
\hline $\begin{array}{l}\text { UDM } \\
(\mathrm{g} / 100 \mathrm{~g}) \\
\end{array}$ & 49 & $8.63 \pm 0.09$ & 11 & $8.25 \pm 0.16$ & 26 & $8.28 \pm 0.05$ & 19 & $8.18 \pm 0.05$ \\
\hline $\mathrm{pH}$ & 49 & $6.50 \pm 0.01$ & 11 & $6.57 \pm 0.02$ & 26 & $6.50 \pm 0.02$ & 19 & $6.47 \pm 0.02$ \\
\hline
\end{tabular}

UDM - unfatty dry matter 
Tab. 2. The differences between the average values of the genotypes from the locus of the $\alpha_{s 1}$-casein concerning the qualitative parameters of goat milk

\begin{tabular}{lcccccc}
\hline Genotypes & $\begin{array}{c}\text { Fatness } \\
(\mathrm{g} / 100 \mathrm{~g})\end{array}$ & $\begin{array}{c}\text { Protein } \\
(\mathrm{g} / 100 \mathrm{~g})\end{array}$ & $\begin{array}{c}\text { Casein } \\
(\mathrm{g} / 100 \mathrm{~g})\end{array}$ & $\begin{array}{c}\text { Lactose } \\
(\mathrm{g} / 100 \mathrm{~g})\end{array}$ & $\begin{array}{c}\text { UDM } \\
(\mathrm{g} / 100 \mathrm{~g})\end{array}$ & $\mathrm{pH}$ \\
\hline $\mathrm{AA}-\mathrm{EE}$ & $0.03^{\text {ns }}$ & $0.42^{\mathrm{x}}$ & $0.32^{\mathrm{x}}$ & $-0.05^{\text {ns }}$ & $0.38^{\mathrm{x}}$ & $-0.07^{\mathrm{xx}}$ \\
\hline $\mathrm{AA}-\mathrm{FF}$ & $0.57^{\text {ns }}$ & $0.51^{\mathrm{xxx}}$ & $0.37^{\mathrm{xxx}}$ & $-0.15^{\mathrm{xx}}$ & $0.63^{\mathrm{xxx}}$ & $0.00^{\text {ns }}$ \\
\hline $\mathrm{AA}-\mathrm{HET}$ & $0.53^{\mathrm{xx}}$ & $0.43^{\mathrm{xx}}$ & $0.31^{\mathrm{xxx}}$ & $0.08^{\text {ns }}$ & $0.45^{\mathrm{xxx}}$ & $0.03^{\text {ns }}$ \\
\hline $\mathrm{EE}-\mathrm{FF}$ & $0.07^{\text {ns }}$ & $0.15^{\text {ns }}$ & $0.05^{\text {ns }}$ & $-0.10^{\text {ns }}$ & $-0.03^{\text {ns }}$ & $0.07^{\mathrm{x}}$ \\
\hline EE $-\mathrm{HET}$ & $0.50^{\mathrm{xx}}$ & $0.01^{\text {ns }}$ & $-0.01^{\text {ns }}$ & $0.13^{\text {ns }}$ & $0.07^{\text {ns }}$ & $0.10^{\text {xx }}$ \\
\hline FF - HET & $0.43^{\text {xx }}$ & $-0.08^{\text {ns }}$ & $-0.06^{\text {ns }}$ & $0.23^{\text {xxx }}$ & $0.10^{\text {ns }}$ & $0.03^{\text {ns }}$ \\
\hline
\end{tabular}

ns - P > 0.05; $\mathrm{x}-\mathrm{P} \leq 0.05 ; \mathrm{xx}-\mathrm{P} \leq 0.01 ; \mathrm{xxx}-\mathrm{P} \leq 0.001$

Tab. 3. Phenotypical correlations between qualitative parameters of the goat milk estimated in genotypes from the $\alpha_{\mathrm{s} 1}$-casein locus

\begin{tabular}{ccccc}
\hline Correlated traits & $\mathrm{AA}$ & $\mathrm{EE}$ & $\mathrm{FF}$ & Heterozygous $^{\mathrm{n}}$ \\
& $\mathrm{n}=49$ & $\mathrm{n}=11$ & $\mathrm{n}=26$ & $-0.006^{\mathrm{ns}}$ \\
\hline UDM X Fatness & $0.700^{\mathrm{xxx}}$ & $0.202^{\mathrm{ns}}$ & $-0.030^{\mathrm{ns}}$ & $0.514^{\mathrm{xx}}$ \\
UDM X Protein & $0.929^{\mathrm{xxx}}$ & $0.899^{\mathrm{xxx}}$ & $0.824^{\mathrm{xxx}}$ & $0.909^{\mathrm{xxx}}$ \\
UDM X Casein & $0.949^{\mathrm{xxx}}$ & $0.934^{\mathrm{xxx}}$ & $0.875^{\mathrm{xxx}}$ & $0.332^{\mathrm{ns}}$ \\
UDM X Lactose & $-0.348^{\mathrm{xx}}$ & $0.546^{\mathrm{ns}}$ & $0.577^{\mathrm{xx}}$ & $0.244^{\mathrm{ns}}$ \\
UDM X pH & $-0.256^{\mathrm{ns}}$ & $0.541^{\mathrm{ns}}$ & $0.124^{\mathrm{ns}}$ & $-0.012^{\mathrm{ns}}$ \\
\hline Protein X Fatness & $0.734^{\mathrm{xxx}}$ & $0.293 \mathrm{~ns}$ & $-0.076^{\mathrm{ns}}$ & $0.676^{\mathrm{xx}}$ \\
Protein X Casein & $0.995^{\mathrm{xxx}}$ & $0.993^{\mathrm{xxx}}$ & $0.926^{\mathrm{xxx}}$ & $-0.218^{\mathrm{ns}}$ \\
Protein X Lactose & $-0.666^{\mathrm{xxx}}$ & $0.127^{\mathrm{ns}}$ & $0.089^{\mathrm{ns}}$ & $0.264^{\mathrm{ns}}$ \\
Protein X pH & $-0.426^{\mathrm{xx}}$ & $0.266^{\mathrm{ns}}$ & $0.066^{\mathrm{ns}}$ & $-0.065^{\mathrm{ns}}$ \\
\hline Casein X Fatness & $0.743^{\mathrm{xxx}}$ & $0.300^{\mathrm{ns}}$ & $-0.061^{\mathrm{ns}}$ & $-0.030^{\mathrm{ns}}$ \\
Casein X Lactose & $-0.614^{\mathrm{xxx}}$ & $0.215^{\mathrm{ns}}$ & $0.875^{\mathrm{xxx}}$ & $0.186^{\mathrm{ns}}$ \\
Casein X pH & $-0.416^{\mathrm{xx}}$ & $0.335^{\mathrm{ns}}$ & $-0.008^{\mathrm{ns}}$ & $0.196^{\mathrm{ns}}$ \\
\hline Lactose X Fatness & $-0.448^{\mathrm{xx}}$ & $-0.127^{\mathrm{ns}}$ & $0.069^{\mathrm{ns}}$ & $0.357^{\mathrm{ns}}$ \\
Lactose X pH & $0.595^{\mathrm{xxx}}$ & $0.742^{\mathrm{xx}}$ & $0.356^{\mathrm{ns}}$ & $0.172^{\mathrm{ns}}$ \\
\hline Fatness X pH & $-0.138^{\mathrm{ns}}$ & $-0.247^{\mathrm{ns}}$ & 0.246 & \\
\hline
\end{tabular}

UDM - unfatty dry matter. ns: $\mathrm{P}>0.05$; $\mathrm{xx}: \mathrm{P}<0.01$; xxx: $\mathrm{P}<0.001$

compared to heterozygous are reported for fat and $\mathrm{pH}$, while for the FF homozygous genotype and heterozygous, differences statistically assured in advantage of the FF genotype are recorded only in fat and lactose contents.

Ourresultsconcerning the averagevalues, differences between genotypes and their significance differ from those obtained by Pop (2012) and Bălteanu (2011) in the same Carpathian breed and for the same qualitative parameters of milk. Thus, Pop (2012) estimates statistically assured differences between AA-EE genotypes only in UDM $(+0.044 \mathrm{~g} / 100 \mathrm{~g})$, between genotypes AA-FF for protein content $(+0.43 \mathrm{~g} / 100 \mathrm{~g})$, casein content
$(+0.29 \mathrm{~g} / 100 \mathrm{~g})$ and in UDM $(+0.27 \mathrm{~g} / 100 \mathrm{~g})$ and between genotypes FF-EE only for lactose content $(+0.13 \mathrm{~g} / 100 \mathrm{~g})$.

The average values of the qualitative parameters analyzed in Carpathian goat breed, by all three categories of analyzed genotypes homozygous at the CSN1S1 locus, which codifies $\alpha_{\mathrm{s} 1}$-casein, differ from those obtained by other authors in similar studies concerning other breeds, in Europe, but majority of studies reflect the superiority of the AA homozygous genotype compared to rest of genotypes for the protein, casein, and UDM contents (Martin and Addeo, 1996; Vassal et al., 1994). In Table 3 are presented the phenotypical 
correlations between the qualitative parameters of the goat milk, estimated in genotypes from the locus of the $\alpha_{\mathrm{s} 1}$-casein.

Within the homozygous genotype AA positive correlations, intense and very significant are recorded between UDM and contents of fat, protein and casein (0.700-0.949); between the content of protein and contents of fat and casein (0.734-0.995); between the content of casein and fat $(0.743)$ and between the content of lactose and $\mathrm{pH}$ (0.595). Within the homozygous genotype AA the lactose content is negatively distinct or very significant correlated with UDM content, total protein, casein and fat, which demonstrates that as low is the lactose content in milk, as high are the contents of UDM, total protein, casein and fat. $\mathrm{pH}$ is also negatively distinct significant correlated with content of total protein and casein content. In other homozygous genotypes (EE and FF) intense and very significant correlations are recorded between the content in UDM and total protein content and casein content (0.824-0.934), as well as between the total protein content and casein content (0.926-0.993).

\section{CONCLUSION}

Concerning the average contents of total protein, casein and UDM, a clear superiority of the AA homozygous genotype was reported compared to other genotypes, thus differences between the average values recorded for genotypes AA-EE are not statistically significant, while between genotypes AA-FF differences are very significant.

The genotyping of the Carpathian goat populations at the locus of $\alpha_{\mathrm{s} 1}$-casein and promotion to reproduction of AA homozygous genotypes, especially, could led to improvement of the milk qualitative parameters and increase of cheese obtaining yield.

Concerning the average content of fat in milk, we also noticed the superiority of AA genotype compared to the other genotypes (EE and FF), but the differences between the average values
$(0.03 \mathrm{~g} / 100 \mathrm{~g}$ and $0.57 \mathrm{~g} / 100 \mathrm{~g}$, respectively) are not statistically significant.

The positive phenotypical correlations, intense and very significant between UDM and contents of fat, protein and casein, and also between the total protein content and contents of fat and casein, within AA genotype, indicate the possibility of performing the simultaneous selection for the improvement of these traits, based on one of these traits that is easier to be determined (e.g., fat or protein contents).

\section{REFERENCES}

1. Bălteanu AV (2011). Effect of $\alpha_{\mathrm{S} 1}$-casein Polymorphisms on Milk Composition and Cheesemaking Efficiency in Carpathian Goat Breed. Bulletin UASMV Animal Science and Biotechnologies, 68 (1-2): 71-76.

2. Caroli A, F Chiatti, S Chessa, D Rignanese, P Bolla, G Pagnacco (2006). Focusing on goat casein complex. J. Dairy Sci.89: 3178-3187.

3. Grosclaude F, MF Mahe, G Brignon, L Di Stasio, R Juenet (1987).A Mendelian polymorphisms underlying quantitative variation of goat $\alpha_{\mathrm{s} 1}$-casein. Gen.Sel. Evol. 19:399-412.

4. Grosclaude F, Martin P (1997). Casein polymorphisms in the goat. In Milk Protein Polymorphism pages 241-253. International Dairy Federation, Brussels, Belgium.

5. Mahe MF, E Manfredi, G Ricardeau, A Piacere, F Grosclaude (1994). Effets du polymorphisme de la caseine $\alpha_{\mathrm{s} 1}$-caprine sur le performances laitieres: analyse intradescendance de boucs de race Alpine. Genet.Sel. Evol. 26:151-157.

6. Martin P, R Addeo (1996). Genetic polymorphisms of casein in the milk of goats and sheep. In: Production and Utilization of Ewe and Goat Milk. Proc. of the IDF/Greek National Committee of IDF/CIRVAL Seminar, Greece, 4558.

7. Pop Felician Dorin (2012). Evaluarea efectului $\alpha_{s 1}-$ cazeinei la rasa de caprine Carpathian asupra calităţii laptelui şi al randamentului de obţinere a brânzeturilor. Teza de doctorat USAMV Cluj-Napoca.

8. Vassal L, A Delacroix-Buchet, J Bouillon (1994). Influence des variants AA, EE et FF de la caseine $\alpha_{\mathrm{s} 1}$ caprine sur le rendement fromager et les caracteristiques sensorielles de fromages traditionnels: premieres observations. Lait 74: 89-103.

9. Vlaic A, Bălteanu VA, Carşai C, Şuteu M (2010). Milk protein polymorphisms study in some carpathian populations rared in the central part of Romania. Bulletin UASMV, Animal Science and Biotechnologies 67, 54-59. 